\title{
Experimental Unit Status Code
}

National Cancer Institute

\section{Source}

National Cancer Institute. Experimental Unit Status Code. NCI Thesaurus. Code C94259.

A coded value specifying the phase in the lifecycle of the experimental unit. 